\title{
Pengaruh Motivasi Terhadap Kinerja Karyawan Pada PT. Hevea Bumi Sriwijaya
}

\author{
Muhammad Najib \\ Pendidikan B. Inggris, FKIP Universitas PGRI Palembang \\ mn760503@gmail.com
}

\begin{abstract}
ABSTRAK
Populasi pada penelitian ini berjumlah 63 karyawan dengan sampel berjumlah 63 karyawan pada PT. Hevea Bumi Sriwijaya. Metode yang digunakan dalam penelitian ini adalah deskritif kuantitatif. Penggunaan metode ini karena selain menggambarkan uraian peneliti ini juga menggambarkan data dalam bentuk angka sebagai acuannya. Teknik dalam pengumpulan data penelitian ini adalah dokumentasi dan kuisioner. Data hasil tes dianalisis dengan uji normalitas, multikoloniaritas, dan uji heteroskedasitas dilanjutkan dengan pengujian hipotesis menggunakan uji regresi sederhana (korelasi, determinan, dan uji t). Berdasarkan analisis data diketahui, 1) Motivasi memiliki pengaruh yang signifikan terhadap kinerja karyawan. Hal ini berarti, apabila motivasi karyawan PT. Hevea Bumi Sriwijaya tinggi maka akan semakin baik kinerja yang dihasilkan oleh seorang karyawan 2) Besarnya pengaruh variabel motivasi terhadap kinerja karyawan sebesar $47,1 \%$ sedangkan sisanya dipengaruhi faktor lain. 3) Nilai beta variabel motivasi sebesar $(b=0,503)$ menunjukkan bahwa setiap variabel Motivasi ditingkatkan sebesar satu satuan, maka kinerja karyawan akan meningkat sebesar 0,503 satuan. Sebaliknya jika variabel motivasi diturunkan satu satuan maka kinerja karyawan akan menurun sebesar 0,503 satuan.
\end{abstract}

Kata Kunci : Motivasi dan Kinerja Karyawan

\section{A. PENDAHULUAN}

Peningkatan sumber daya manusia merupakan titik sentral bagi pembangunan nasional. Hal ini disebabkan peranan sumber daya manusia merupakan unsur yang paling utama dalam proses pembangunan. Begitu juga peranan karyawan dalam suatu perusahaan sangat penting. Pegawai merupakan penggerak utama dalam suatu proses pelaksanaan operasional serta menentukan lancarnya aktivitas suatu instansi. Dengan demikian potensi karyawan yang ada di dalam perusahaan itu diperlukan adanya suatu pemanfaatan yang benar-benar efektif, sehingga diharapkan dapat menghasilkan suatu penyelesaian tugas secara tepat, berdaya guna dan berhasil guna.

Manusia merupakan unsur terpenting dan paling menentukan bagi kelancaran jalannya proses manajemen, maka hal-hal yang berhubungan dengan motivasi perlu mendapat perhatian yang sungguhsungguh dari setiap pimpinan guna keberhasilan suatu organisasi. Apabila motivasi tersebut diiringi dengan kemampuan yang dimiliki karyawan dalam melaksanakan pekerjaannya, maka karyawan tersebut diharapkan dapat menggerakkan, mengerahkan dan mengarahkan segala sumber daya yang dimilikinya untuk mengoptimalkan prestasi kerjanya.

Keberhasilan suatu organisasi untuk mencapai tujuan yang diharapkan tergantung pada kualitas sumber daya manusianya. Oleh karena itu, sebuah organisasi harus memiliki pegawai yang berkualitas, bertanggung jawab, disiplin yang tinggi serta memiliki motivasi, semangat, dan loyalitas tinggi yang tercermin dari kinerja seorang karyawan.

Kinerja pada umumnya diartikan sebagai kesuksesan seseorang didalam melaksanakan suatu pekerjaan. Kinerja karyawan 
merupakan hasil kerja yang dicapai seseorang dalam melaksanakan tugas-tugas yang dibebankan kepadanya. Kinerja karyawan meliputi kualitas dan kuantitas output serta keandalan dalam bekerja. Karyawan dapat bekerja dengan baik bila memiliki kinerja yang tinggi sehingga dapat menghasilkan kerja yang baik pula. Dengan adanya kinerja yang tinggi yang dimiliki karyawan, diharapkan tujuan organisasi dapat tercapai. Sebaliknya, tujuan organisasi susah atau bahkan tidak akan tercapai bila karyawan bekerja tidak memiliki kinerja yang baik, sehingga tidak dapat menghasilkan kerja yang baik pula.

Dalam melakukan atau mengerjakan suatu pekerjaan, perlu adanya suatu pendorong atau motivasi. Dengan adanya motivasi, maka orang bekerja dengan lebih bersemangat dan lebih giat untuk mencapai tujuan yang diinginkan. Motivasi merupakan bagian dari perilaku organisasi yang menyangkut dorongan yang memberikan semangat kerja kepada para pegawai untuk berperilaku dan untuk mencapai tujuan dalam suatu organisasi yang telah ditetapkan. Setiap manusia melakukan sesuatu atau berbuat sesuatu pada dasarnya karena didorong oleh suatu motivasi tertentu.

Dalam prinsip manajemen motivasi merupakan sebab pikiran dasar atau golongan bagi seseorang untuk berbuat sesuatu ide pokok yang selalu berpengaruh besar terhadap tingkah laku manusia. Sedangkan masalah pokok dalam memotivasi adalah bagaimana cara terbaik untuk mengusahakan agar bawahan dapat selalu berprestasi secara maksimal untuk kepentingan organisasi atau perusahaan. Dalam meningkatkan kinerja karyawan, faktor motivasi kerja dari atasan sangat penting dilakukan. Motivasi menjadi pendorong seseorang untuk melaksanakan kegiatan guna mendapatkan hasil yang terbaik. Oleh karena itu tidak heran jika karyawan mempunyai motivasi kerja tinggi biasanya mempunyai kinerja yang tinggi pula (Mangkunegara, 2013).

Kinerja PT. Hevea Bumi Sriwijaya sudah cukup baik, namun masih sering terjadi peningkatan dan penurunan kinerja karyawannya. Dari hasil wawancara yang dilakukan bahwa kinerja seorang karyawan dapat meningkat dan menurun setiap waktu. Dengan demikian fenomena yang akan dikaji adalah apa yang menyebabkan kinerja itu dapat meningkat dan menurun, apakah karena motivasi yang diberikan kepada karyawan sudah cukup baik atau masih kurang.

\section{B. KAJIAN TEORI \\ Motivasi}

Istilah motivasi berasal dari bahasa latin yaitu kata movere yang berarti bergerak. Dalam konteks sekarang, motivasi dapat didefinisikan sebagai suatu proses psikologi yang menghasilkan suatu intensitas, arah, dan ketekunan individual dalam usaha untuk mencapai satu tujuan. Motivasi adalah suatu pendorong yang mengubah energi dalam diri seseorang ke dalam bentuk aktifitas nyata untuk mencapai tujuan (Djamarah, 2011).

Hasibuan (2010) mendefinisikan motivasi adalah pemberian daya penggerak yang menciptakan kegairahan kerja seseorang, agar mereka mau bekerja sama secara produktif berhasil mencapai dan mewujudkan tujuan yang telah ditentukan. Berendoom dan Stainer dalam Brantas (2010) mendefinisikan motivasi adalah kondisi mental yang mendorong aktivitas dan memberi energi yang mengarah kepada pencapaian kebutuhan memberi 
kepuasan atau mengurangi ketidakseimbangan.

Kebutuhan didefinisikan suatu kesenjangan atau pertentangan yang di alami antara suatu kenyataan dengan dorongan yang ada dalam diri. Apabila karyawan kebutuhannya tidak terpenuhi maka pegawai tersebut akan menunjukkan perilaku kecewa. Sebaliknya jika kebutuhannya terpenuhi maka karyawan tersebut akan memperlihatkan perilaku yang gembira sebagai manifestasi dari rasa puasnya. Lima kebutuhan manusia menurut Maslow, antara lain: physiological needs (kebutuhan fisik), security or safety needs (kebutuhan keselamatan), affiliation or acceptance (kebutuhan sosial), esteem or status needs (kebutuhan akan penghargaan prestise), dan self actualization (aktualisasi diri).

Teori motivasi McClelland beranggapan bahwa karyawan potensial. Bagaimana energi dilepaskan dan digunakan tergantung pada kekuatan dorongan motivasi seseorang dan situasi serta peluang yang tersedia. Energi akan dimanfaatkan oleh karyawan karena didorong oleh motif, harapan dan insentif. McClelland dalam Brantas, (2010) lebih jelas tiga energy yang dapat mendorong karyawan mencapai kinerja yang tinggi, sebagai berikut:

1. Motif adalah suatu perangsang keinginan (want) dan daya penggerak kemauan bekerja seseorang. Setiap motif mempunyai tujuan tertentu yang ingin dicapai.

2. Harapan (expectancy) adalah suatu kesempatan yang diberikan terjadi karena perilaku untuk tercapainya tujuan. Harapan adalah kadar kuatnya keyakinan bahwa upaya kerja akan menghasilkan penyelesaian suatu tugas. Harapan dinyatakan sebagai kemungkinan (probability) perkiraan pegawai tentang kadar sejauh mana prestasi yang dicapai ditentukan oleh upaya yang dilakukan (Davis dan Newstroom dalam Makmur, 2011).

3. Insentif (incentive) yaitu memotivasi (merangsang) bawahan dengan memberikan hadiah (imbalan) kepada mereka yang berprestasi di atas prestasi standar. Dengan demikian semangat kerja bawahan akan meningkat karena umumnya manusia senang menerima yang baik-baik saja. Ndarda dalam Makmur (2011) mengartikan insentif sebagai perangsang dari luar diri manusia. Insentif memiliki peranan dalam kompensasi. Adakalanya insentif yang disebut belakangan menyediakan tambahan motivasi yang cukup untuk menimbulkan peningkatan prestasi yang diinginkan. Pada prinsipnya insentif terbagi menjadi dua macam, yaitu insentif material atau upah dan insentif nonmaterial. Insentif material atau upah berasal dari teori.

Davis dan Newstroom dalam Makmur (2011), dimana dikemukakan sebagai berikut: insentif upah merupakan proses yang rumit dan dapat menimbulkan banyak kesulitan misalnya sebagai berikut:

1. Insentif upah biasanya mensyaratkan penetapan standar prestasi;

2. Insentif upah dapat memperumit pekerjaan para penyelia;

3. Masalah yang sulit dengan insentif upah adalah goyahnya harkat;

4. Insentif upah dapat menimbulkan ketidakharmonisan antara karyawan;

5. Kesulitan lain dengan insentif upah adalah bahwa insentif seperti itu dapat menimbulkan pembatasan keluaran (output restriction). 
Berdasarkan pengertian para ahli di atas, dapat disimpulkan bahwa motivasi adalah dorongan/penggerak yang ada dalam diri seseorang untuk melakukan aktivitas-aktivitas yang dia inginkan atau memiliki tujuan tertentu pada lingkungan yang ada di sekitarnya.

\section{Jenis-Jenis Motivasi}

Djamarah (2011) mengatakan bahwa yang dimaksud dengan motivasi instrinsik adalah motif-motif yang menjadi aktif dan berfungsinya tidak perlu dirangsang dari luar, karena dalam setiap diri individu sudah ada dorongan untuk melakukan sesuatu. Bila seseorang telah memiliki motivasi instrinsik maka ia secara sadar akan melakukan sesuatu kegiatan yang tidak memerlukan motivas dari luar dirinya. Sebagai contoh seseorang yang senang membaca tidak usah ada yang menyuruh atau mendorongnya karena ia sudah rajin mencari bukubuku untuk dibacanya. Dari pendapat ahli di atas, dapat disimpulkan bahwa motivasi instrinsik adalah motivasi yang bersumber dari dalam diri seseorang yang mendorongnya untuk mengerjakan atau melakakukan sesuatu.

Djamarah (2011) bahwa motivasi ekstrinsik adalah kebalikan dari motivasi instrinsik. Motivasi esktrinsik adalah motif-motif yang aktif dan berfungsi karena adanya perangsang dari luar. Motivasi ekstrinsik bukan berarti motivasi yang tidak diperlukan dan tidak baik dalam pendidikan. Motivasi ekstrinsik diperlukan agar seseorang mau melakukan sesuatu. Sardiman (2010) bahwa motivasi ekstrinsik adalah dorongan dari luar diri, tindakan atau perbuatan yang didasari oleh dorongan-dorongan yang bersumber dari luar pribadi seseorang (lingkungan) untuk melakukan sesuatu karena adanya paksaan dari luar.
Berangkat dari uraian diatas, dapat diambil kesimpulan bahwa motivasi ekstrinsik adalah dorongan yang berasal dari luar diri seseorang, baik dari lingkungan ataupun yang lainnya seperti motivasi berprestasi, motivasi dari masyarakat dan temanteman pergaulan.

\section{Faktor yang mempengaruhi Motivasi}

Menurut para ahli motivasi pada diri seseorang tidak terjadi secara tibatiba melainkan melalui proses. Kebutuhan fisiologis dan keamanan, kadang sering juga diklasifikasikan dengan cara lain, misalnya dengan menggolongkannya sebagai kebutuhan primer, sedangkan yang lainnya dikenal pula dengan klasifikasi kebutuhan sekunder. Terlepas dari cara membuat klasifikasi kebutuhan manusia itu, yang jelas adalah bahwa sifat, jenis dan intensitas kebutuhan manusia berbeda satu orang dengan yang lainnya karena manusia merupakan individu yang unik. Juga jelas bahwa kebutuhan manusia itu tidak hanya bersifat materi, akan tetapi bersifat pskologikal, mental, intelektual dan bahkan juga spiritual.

\section{Indikator Motivasi}

Indikator motivasi kerja dalam penelitian ini menggunakan teori dan Herzberg dalam Slamet (2017) yaitu:

1. Hubungan dengan rekan kerja dan atasan, suasana harmonis antar pegawai tenjalin ditempat kerja dan selalu terjalin kerjasama bawahan dengan atasan maupun dengan rekan kerja.

2. Lingkungan kerja, Terdapat fasilitas penunjang pekerjaan yang memadai sesuai dengan tuntutan kerja dan suasana kerja yang sesuai dengan yang di harapkan.

3. Kesempatan meningkatkan pengetahuan dan keterampilan, Perusahaan atau organisasi telah 
memberikan pendidikan dan pelatihan bagi pegawainya.

4. Pemberian tunjangan, Perusahaan atau organisasi telah memberikan tunjangan yang layak bagi pegawainya.

\section{Kinerja Pegawai}

Istilah Kinerja sering digunakan untuk menyebut prestasi atau tingkat keberhasilan individu maupun kelompok individu. Kinerja bisa diketahui hanya jika individu atau kelompok individu mempunyai kriteria keberhasilan yang telah ditetapkan. Kriteria keberhasilan ini berupa tujuantujuan atau target-target tertentu yang hendak dicapai. Tanpa ada tujuan atau target, kinerja seseorang atau organisasi tidak mungkin dapat diketahui karena tidak ada tolak ukurnya.

Mahsun (2010) mendefinisikan bahwa kinerja (performance) sebagai gambaran mengenai tingkat pencapaian pelaksanaan suatu kegiatan atau program atau kebijakan dalam mewujudkan sasaran, tujuan, misi dan visi organisasi yang tertuang dalam rencana strategic planning suatu organisasi. Istilah kinerja sering digunakan untuk menyebut prestasi atau tingkat keberhasilan individu maupun kelompok individu. Kinerja bisa diketahui hanya jika individu atau kelompok individu mempunyai kriteria keberhasilan yang telah ditetapkan. Kriteria keberhasilan ini berupa tujuantujuan atau target-target tertentu yang hendak dicapai. Tanpa ada tujuan atau target, kinerja seseorang atau organisasi tidak mungkin dapat diketahui karena tidak ada tolak ukurnya.

Menurut Davis (2012), bahwa faktor-faktor yang mempengaruhi kinerja adalah "faktor kemampuan (ability) dan faktor motivasi (motivation)". Secara psikologis, kemampuan karyawan terdiri dari kemampuan potensi (IQ) dan kemampuan sebenarnya (Knowledge + Skill). Artinya karyawan yang memiliki IQ di atas rata-rata dengan pendidikan yang memadai untuk jabatannya dan keterampilan dalam mengerjakan pekerjaan, maka akan lebih mudah mencapai kinerja yang diharapkan.

Kinerja mengacu pada prestasi karyawan yang diukur berdasarkan standar atau kriteria yang ditetapkan perusahan.Pengertian kinerja atau prestasi kerja diberi batasan oleh Maier dalam As'ad, (2011) sebagai "kesuksesan seseorang di dalam melaksanakan suatu pekerjaan".Lebih tegas lagi Lawler and Poter menyatakan bahwa kinerja adalah "Succesfull role achievement" yang diperoleh seseorang dari perbuatanperbuatannya (As'ad,2011). Dari batasan tersebut di atas menyimpulkan bahwa kinerja adalah hasil yang dicapai seseorang menurut ukuran yang berlaku untuk pekerjaan yang bersangkutan.

Menurut Prawirosentono (2015) bahwa Kinerja pegawai adalah hasil kerja yang dapat dicapai seseorang atau sekolompok orang dalam suatu organisasi dengan wewenang dan tanggung jawab masing-masing, dalam rangka upaya mencapai tujuan organisasi bersangkutan secara legal, tidak melanggar hukum dan sesuai dengan moral dan etika. Dalam Fahmi (2015) bahwa Kinerja adalah hasil yang diperoleh oleh suatu organisasi baik organisasi tersebut bersifat memiliki tujuan dan tidak memiliki tujuan yang dihasilkan selama satu periode waktu. Secara lebih tegas Amstron dan Baron dalam Fahmi (2015) mengatakan Kinerja merupakan hasil pekerjaan yang mempunyal hubungan kuat dengan tujuan strategis 
organisasi, kepuasan konsumen dan memberikan kontribusi ekonomi.

Menurut Prawirosentono (2015) bahwa Tercapainya tujuan lembaga atau perusahaan hanya dimungkinkan karena upaya para pelaku yang terdapat pada organisasi lembaga atau perusahaan tersebut. Dalam hal ini sebenarnya terdapat hubungan yang erat antara kinerja perorangan (Individual performance) dengan kinerja lembaga (Institutional performance) atau kinerja perusahaan (Corporate performance). Dengan perkataan lain bila kinerja karyawan (Individual performance) baik maka kemungkinan besar kinerja perusahaan (Corporate performance) juga baik. Kinerja seorang pegawai akan baik bila dia mempunyai keahlian (Skill) yang tinggi, bersedia bekerja karena digaji atau diberi upah sesuai dengan perjanjian, mempunyai harapan (Expectation) masa depan lebih baik.

Mengenai gaji dan adanya harapan (Expectation) merupakan hal yang menciptakan motivasi seorang karyawan bersedia melaksanakan kegiatan kerja dengan kinerja yang baik. Bila sekelompok karyawan dan atasannya mempunyai kinerja yang baik, maka akan berdampak pada kinerja perusahaan yang baik pula.

Menurut Schuler dan Jackson dalam Harsuku (2011) bahwa ada 3 jenis dasar kriteria kinerja yaitu:

1. Kriteria berdasarkan sifat memusatkan diri pada karakteristik pribadi seseorang karyawan. Loyalitas, keandalan, kemampuan berkomunikasi, dan keterampilan memimpin merupakan sifat-sifat yang sering dinilai selama proses penilaian. Jenis kriteria ini memusatkan diri pada bagaimana seseorang, bukan apa yang dicapai atau tidak dicapai seseorang dalam pekerjaanya.
2. Kriteria berdasarkan perilaku terfokus pada bgaimana pekerjaan dilaksanakan. Kriteria semacam ini penting sekali bagi pekerjaan yang membutuhkan hubungan antar personal. Sebagai contoh apakah SDM-nya ramah atau menyenangkan.

3. Kriteria berdasarkan hasil, kriteria ini semakin populer dengan makin ditekanya produktivitas dan daya saing internasional. Kreteria ini berfokus pada apa yang telah dicapai atau dihasilkan ketimbang bagaimana sesuatu dicapai atau dihasilkan.

Menurut Bernandin \& Russell dalam (Riani,2011) bahwa kriteria yang digunakan untuk menilai kinerja pegawai adalah sebagai berikut:

1. Kuantitas Kerja (Quantity of Work): jumlah kerja yang dilakukan dalam suatu periode yang ditentukan.

2. Kualitas Kerja (Quality of Work): kualitas kerja yang dicapai berdasarkan syarat-syarat kesesuaian dan ditentukan.

3. Pengetahuan Pekerjaan (Job Knowledge) : luasnya pengetahuan mengenai pekerjaan dan keterampilannya.

4. Kreativitas (Creativeness): keaslian gagasan-gagasan yang dimunculkan dan tindakan-tindakan untuk menyelesaikan persoalanpersoalan yang timbul.

5. Kerja Sama (Cooperation): kesedian untuk bekerjasama dengan orang lain atau sesama anggota organisasi.

6. Ketergantungan (Dependability): kesadaran untuk mendapatkan kepercayaan dalam hal kehadiran dan penyelesaian kerja.

7. Inisiatif (Initiative): semangat untuk melaksanakan tugas-tugas baru dan dalam memperbesar tanggung jawabnya. 
8. Kualitas Personal (Personal Qualities): menyangkut kepribadian, kepemimpinan, keramah-tamahan dan integritas pribadi.

Hasibuan (2010) menjelaskan penilaian kinerja karyawan berguna bagi perusahaan dan bermanfaat bagi karyawan. Oleh karena itu tujuan dan kegunaan penilaian kinerja, sebagai berikut:

1. Sebagai dasar dalam pengambilan keputusan yang digunakan untuk promosi, demosi, pemberhentian, dan penetapan besarnya balas jasa.

2. Untuk mengukur prestasi kerja yaitu sejauh mana karyawan bisa sukses dalam pekerjaannya.

3. Sebagai dasar untuk mengevaluasi efektivitas seluruh kegiatan di dalam perusahaan.

4. Sebagai dasar untuk mengevaluasi program latihan dan keefektifan jadwal kerja, metode kerja, struktur organisasi, gaya pengawasan, kondisi kerja, dan peralatan kerja.

5. Sebagai indikator untuk menentukan kebutuhan latihan bagi karyawan yang berada di dalam organisasi.

6. Sebagai alat untuk meningkatkan motivasi kerja karyawan sehingga dicapai tujuan untuk mendapatkan performance kerja yang baik.

\section{Faktor yang Mempengaruhi Kinerja}

Menurut Prawirosenotono (2015) ada 4 hal yang mempengaruhi kinerja seseorang dalam organisasi atau perusahaan tempatnya bekerja sebagai berikut.

1. Efektivitas dan Efisiensi. Bila suatu tujuan tertentu akhirnya dapat dicapai, kita boleh mengatakan bahwa kegiatan tersebut adalah efektif. Tetapi bila akibat yang tidak dicari dan kegiatan mempunyai nilai yang lebih penting dibandingkan dengan hasil yang tercapai, sehingga mengakibatkan ketidakpuasan walaupun efektif, hal ini disebut tidak efisien. Sebaliknya bila akibat yang tidak dicari-cari tidak penting atau remeh, maka kegiatan tersebut efisien". Sehubungan dengan itu, kita dapat mengatakan sesuatu efektif bila mencapai tujuan tertentu. Dikatakan efisien bila hal itu memuaskan sebagai pendorong mencapai tujuan, terlepas apakah efektif atau tidak. Efektivitas dan usaha kerja sama (antar individu) berhubungan dengan pelaksanaan yang dapat mencapai suatu tujuan dalam suatu sistem, dan hal itu ditentukan dengan suatu pandangan dapat memenuhi kebutuhan system itu sendiri. Sedangkan efisiensi dari suatu kerja sama dalam system (antar individu) adalah hasil gabungan efisiensi dari upaya yang dipilih masing-masing individu.

2. Otoritas dan tanggung jawab (Autority dan Responsibility). Authority adalah sifat dan suatu komunikasi atau perintah dalam suatu organisasi formal yang dimiliki (diterima) oleh seorang peserta organisasi kepada para anggota organisasi lain untuk melakukan suatu kegiatan kerja, sesuai dengan kontribusinya tenaganya).

(sumbangan

3. Disiplin (Discipline). Disiplin meliputi ketaatan dan hormat terhadap perjanjian yang dibuat antara perusahaan dan pegawai. Disiplin juga berkaitan erat dengan sanksi yang perlu dijatuhkan kepada pihak yang melanggar. Dalam hal seorang pegawai melanggar peraturan yang berlaku dalam organisasi perusahaan, maka pegawai bersangkutan harus sanggup menerima hukuman yang telah disepakati. Masalah disiplin para peserta organisasi baik dia atasan 
(Superordinate) maupun bawahan (Subordinate) akan memberi corak terhadap kinerja organisasi.

4. Inisiatif (Initiative). Seperti disinggung di atas bahwa disiplin memang suatu yang positif apabila diterapkan dalam suatu organisasi untuk mencapai tujuannya. Disiplin adalah sikap dan kemauan mentaati berbagai perturan pemerintah maupun perusahaan. Namun disiplin saja tanpa disertai oleh sikap inisiatif para peserta organisasi perusahaan.

\section{Indikator-Indikator Kinerja Pegawai}

Pada prinsipnya penilaian adalah merupakan cara pengukuran kontribusi-kontribusi dari individu dalam instansi yang dilakukan terhadap organisasi. Nilai penting dari penilaian kinerja adalah menyangkut penentuan tingkat kontribusi individu atau kinerja yang diekspresikan dalam penyelesaian tugas-tugas yang menjadi tanggung jawabnya (Prawirosentono,2015).

Mahsun (2010) berpendapat terdapat 4 (empat) elemen pokok untuk mengukur kinerja, antara lain:

1. Menetapkan tujuan, sasaran, dan strategi organisasi

2. Merumuskan indikator dan ukuran kinerja,

3. Mengukur tingkat ketercapaian tujuan dan sasaran-sasaran organisasi,

4. Evaluasi kinerja. Dalam organisasi publik, system penilaian kinerja sangat diperlukan karena mempunyai peranan kunci dalam proses pengawasan kerja. Penilaian kinerja dapat dilakukan dengan pengukuran kontribusi pegawai terhadap organisasi untuk mencapai tujuan yang ingin dicapai.

Hasibuan (2010) menjelaskan penilaian kinerja karyawan berguna bagi perusahaan dan bermanfaat bagi pegawai. Oleh karena itu tujuan dan kegunaan penilaian kinerja, sebagai berikut:

1. Sebagai dasar dalam pengambilan keputusan yang digunakan untuk promosi, demosi, pemberhentian, dan penetapan besarnya balas jasa.

2. Untuk mengukur prestasi kerja yaitu sejauh mana karyawan bisa sukses dalam pekerjaannya.

3. Sebagai dasar untuk mengevaluasi efektivitas seluruh kegiatan di dalam perusahaan.

4. Sebagai dasar untuk mengevaluasi program latihan dan keefektifan jadwal kerja, metode kerja, struktur organisasi, gaya pengawasan, kondisi kerja, dan peralatan kerja.

5. Sebagai indikator untuk menentukan kebutuhan latihan bagi karyawan yang berada di dalam organisasi.

6. Sebagai alat untuk meningkatkan motivasi kerja karyawan sehingga dicapai tujuan untuk mendapatkan performance kerja yang baik.

Menurut Wibowo (2014) bahwa indikator-indikator kinerja karyawan adalah sebagai berikut:

1. Tujuan, merupakan keadaan yang berbeda yang secara aktif dicari oleh seorang individu atau organisasi untuk dicapai. Tujuan merupakan suatu keadaan yang lebih baik yang ingin dicapai dimasa yang akan datang.

2. Standar, mempunyai arti penting karena memberitahukan kapan suatu tujuan dapat diselesaikan. Standar merupakan suatu ukuran apakah tujuan yang diinginkan dapat tercapai.

3. Umpan balik, melaporkan kemajuan, baik kualitas maupun kuantitas dalam mencapai tujuan yang didefinisikan oleh standar. Umpan balik merupakan masukan yang dipergunakan untuk mengukur 
kemajuan kinerja, standar kinerja. datam pencapaian tujuan.

4. Alat atau sarana, merupakan sumber daya yang dapat digunakan untuk membantu menyelesaikan tujuan dengan sukses. Alat atau sarana merupakan faktor penunjang untuk mencapai tujuan.

5. Kompetisi, mempakan persyaratan utama dalam kinerja, Kompetisi merupakan kemampuan yang dimiliki oleh seseorang unhik menjalankan pekerjaan yang. diberikan kepadannya dengan baik. Orang yang harus melakukan lebih standar belajar tentang sesuatu, orang harus dapat melakukan pekerjaan dengan baik.

6. Motif, merupakan alat atau pendorong bagi seseorang untuk melakukan sesuatu.

7. Peluang, pekerjaan perlu mendapatkan kesempatan untuk menunjukkan prestasi kerjanya.

\section{METODE PENELITIAN}

Menurut Sugiyono (2017) metode penelitian merupakan cara ilmiah untuk mendapatkan data dengan tujuan tertentu. Adapun metode penelitian yang digunakan pada penelitian ini adalah Deskriptif Kuantitatif. Pengguna metode ini karena selain menggambarkan uraian, juga menggunakan data dalam bentuk angka sebagai acuannya.

\section{POPULASI DAN SAMPEL \\ 1) Populasi Penelitian}

Menurut Sugiyono

(2017), populasi adalah wilayah generalisasi yang terdiri atas: objek/subyek yang mempunyai kualitas dan karakteristik tertentu yang ditetapkan oleh peneliti untuk dipelajari dan kemudian ditarik kesimpulannya. Dari pengertian di atas yang dimaksud dengan populasi dalam penelitian ini adalah suatu objek peneliti dalam mengumpulkan data untuk dipelajari dan ditarik kesimpulannya. Populasi dalam penelitian ini adalah karyawan di lingkungan PT. Hevea Bumi Sriwijaya sebanyak 63 orang.

\section{2) Sampel Penelitian}

Sampel adalah bagian dari jumlah dan karekteristik yang dimiliki oleh populasi tersebut (Sugiyono, 2017). Dari pengertian di atas yang dimaksud dengan sampel dalam penelitian ini adalah sebagian individu yang mempunyai sifat yang sama untuk diteliti dan mewakili seluruh populasi. Dikarenakan sampel penelitian kurang dari 100 orang, maka populasi penelitian dianggap sebagai sampel yakni sebanyak 63 orang. dari pegawai PT. Hevea Bumi Sriwijaya.

\section{E. TEKNIK PENGUMPULAN DATA}

Dalam melakukan penelitian ini, peneliti dibantu dengan metode penelitian sebagai berikut:

\section{Dokumentasi}

Dokumen adalah catatan peristiwa yang sudah berlalu. Dokumen bisa berbentuk tulisan, gambar, atau karya monumental dari seseorang (Sugiyono, 2017). Teknik ini dilakukan dengan mengumpulkan data-data yang berkaitan dan berhubungan dengan lokasi penelitian dan subjek penelitian.

\section{Kuesioner (Angket)}

Kuesioner merupakan teknik pengumpulan data yang dilakukan dengan cara memberi seperangkat pertanyaan atau peryataan tertulis kepada responden untuk dijawab (Sugiyono,2017). Kuisioner tersebut disebarkan kepada responden yang menjadi sempel dalam penelitian ini. Angket yang peneliti berikan kepada responden berupa daftar pernyataan, dalam bentuk skala likert dengan jumlah 20 butir pertanyaan. 
Pertanyaan yang terdiri dari 10 jumlah butir variabel $X$ dan 10 jumlah butir variabel $\mathrm{Y}$ dengan alternatif jawaban yakni :

\section{Tabel 1}

Alternatif Jawaban Responden

\begin{tabular}{|c|l|c|}
\hline No & \multicolumn{1}{|c|}{ Kategori } & Skor \\
\hline 1 & Sangat Setuju & 5 \\
\hline 2 & Setuju & 4 \\
\hline 3 & Ragu-Ragu & 3 \\
\hline 4 & Tidak Setuju & 2 \\
\hline 5 & Sangat Tidak Setuju & 1 \\
\hline
\end{tabular}

\section{F. TEKNIK ANALISIS DATA}

1. Regresi Linear Sederhana

Pengujian hipotesis dalam penelitian ini, dianalisis dengan menggunakan Regresi Linear Sederhana (Ridwan, 2012) :

$$
\begin{aligned}
& Y^{s}=a+b X \\
& \text { Keterangan : } \\
& Y=\text { Variabel dependent (Kinerja karyawan) } \\
& \mathrm{X}=\text { Variabel Independent (Kinerja karyawan) } \\
& \mathrm{a}=\text { Nilai konstanta } \\
& \mathrm{b}=\text { Koefesien Regresi. }
\end{aligned}
$$

\section{Koefisien Determinasi}

Koefesien determinasi adalah angka yang menyatakan atau digunakan untuk mengetahui koefesien atau koreal yang diberikan sebuah variabel atau lebih $X$ (bebas) terhadap variabel $Y$ (terikat) (Siregar,2013). Untuk menghitung koefisien determinasi dengan rumus sebagai berikut:

$$
\mathrm{KP}=\mathrm{r}^{2} \times 100 \%
$$

Keterangan:

$\mathrm{R}=$ Koefesien Determinasi

$r^{2}=$ Koefesien Korelasi

\section{Uji t}

Uji t dilakukan untuk mengetahui ada tidaknya pengaruh yang signifikan antara kedua variabel. Menurut
Priyatno (2016) bahwa uji t digunakan untuk mengetahui apakah variabel independen $(X)$ berpengaruh secara siginifikan terhadap variabel Dependent $(Y)$. Taraf signifikan yang digunakan sebesar 5\%. Adapun rumus Uji-t sebagai berikut:

$$
\begin{aligned}
& t=\frac{r \sqrt{n-2}}{\sqrt{1-r^{2}}} \\
& \text { Keterangan : } \\
& \begin{array}{ll}
\text { thitung } \quad=\text { Nilai } t \\
\mathrm{r} \quad=\text { Nilai korelasi } \\
\mathrm{n} \quad=\text { Sampel }
\end{array}
\end{aligned}
$$

Kriteria pengujian hipotesis dalam penelitian ini adalah sebagai berikut : Jika jika thitung $\geq t_{\text {tabel, }}$ maka Ho ditolak Jika jika $t_{\text {hitung }} \leq t_{\text {tabel, }}$ maka Ho diterima.

\section{G. HASIL PENELITIAN}

\section{Analisis Regresi Linier Sederhana}

Analisis regresi linear sederhana digunakan untuk memprediksi seberapa jauh perubahan nilai variabel dependen, bila nilai variabel independen dirubah-rubah atau dinaikturunkan perhitungan statistik dalam analisis regresi linear sederhana selengkapnya ada pada lampiran dan selanjutnya dijelaskan pada tabel berikut ini. 
Tabel 2

Coefficients $^{\mathrm{a}}$

Hasil Analisis Regresi Berganda

\begin{tabular}{|c|c|c|c|c|c|c|}
\hline \multirow[b]{2}{*}{ Model } & & \multicolumn{2}{|c|}{$\begin{array}{l}\text { Unstandardized } \\
\text { Coefficients }\end{array}$} & \multirow{2}{*}{\begin{tabular}{|l} 
Standardized \\
Coefficients \\
Beta \\
\end{tabular}} & \multirow[b]{2}{*}{$\mathrm{t}$} & \multirow[b]{2}{*}{ Sig. } \\
\hline & & B & Std. Error & & & \\
\hline 1 & (Constant) & 18.244 & 4.324 & & 4.219 & .000 \\
\hline & Motivasi & .503 & .116 & .487 & 4.352 & .000 \\
\hline
\end{tabular}

a. Dependent Variable: Kinerja karyawan

Sumber: Output SPSS 22, 2017

Model persamaan regresi yang dapat dituliskan dari hasil tersebut dalam bentuk persamaan regresi adalah sebagai berikut :

$Y=a+b X$

Dengan demikian berdasarkan hasil Tabel 2 adalah:

$\mathrm{Y}=$ Kinerja karyawan

a $($ constanta $)=18,244$

$b_{1}$ (Motivasi) $=0,503$

Diperoleh persamaan:

$\mathrm{Y}=18,244+0,503 \mathrm{X}$

1. $\mathrm{a}=18,244$

Nilai konstanta ini menunjukkan bahwa apabila tidak ada variabel independent (Motivasi) $\mathrm{X}=0$, maka kinerja karyawan adalah 18,244

2. $b=0,503$
Koefisien regresi b ini menunjukkan bahwa setiap variabel Motivasi ditingkatkan sebesar satu satuan, maka kinerja karyawan akan meningkat sebesar 0,503 satuan. Sebaliknya jika variabel motivasi diturunkan satu satuan maka kinerja karyawan akan menurun sebesar 0,503 satuan. Dengan asumsi variabel lain konstan.

\section{Analisis Koefisien Korelasi}

Koefisien korelasi ini digunakan untuk mengukur hubungan atara variabel bebas terhadap variabel terikat. Koefisien korelasi ini digunakan untuk melihat hubungan antara variabel Motivasi $(X)$ dengan variabel kinerja pegawai $(\mathrm{Y})$.

Tabel 3

Hasil Analisis Koefisien Korelasi

Model Summary

\begin{tabular}{|l|l|l|l|l|}
\hline Model & $\mathrm{R}$ & $\mathrm{R}$ Square & $\begin{array}{c}\text { Adjusted } \mathrm{R} \\
\text { Square }\end{array}$ & $\begin{array}{l}\text { Std. Error of } \\
\text { the Estimate }\end{array}$ \\
\hline 1 & .687 & .471 & .321 & 4.25384 \\
\hline
\end{tabular}

a. Predictors: (Constant), Motivasi

Sumber: Output SPSS 22, 2017

Dari hasil perhitungan dengan menggunakan program SPSS versi 22 dapat diketahui bahwa koefisien korelasi (R) yang diperoleh sebesar 0,687 . Hal ini berarti variabel Motivasi mempunyai hubungan yang cukup kuat terhadap kinerja karyawan PT. Hevea Bumi Sriwijaya. 
Koefisien Determinasi $\left(\mathbf{R}^{2}\right)$

Koefisien determinasi ini digunakan untuk mengetahui seberapa besar pengaruh variabel-variabel bebas memiliki pengaruh terhadap variabel terikatnya.

Dari hasil perhitungan dengan menggunakan program SPSS versi 22 dapat diketahui bahwa koefisien determinasi ( $R$ Square) yang diperoleh sebesar 0,471. Hal ini berarti 47,1\% kinerja karyawan dapat dipengaruhi oleh variabel Motivasi, sedangkan sisanya yaitu $52,9 \%$ kinerja karyawan dipengaruhi oleh variabel-variabel lainnya yang tidak diteliti dalam penelitian ini.

\section{Uji Hipotesis Parsial (Uji t)}

Uji t digunakan untuk mengetahui pengaruh secara parsial variabel independen (Motivasi) terhadap variabel dependen (kinerja karyawan). Dimana $\mathrm{dk}=\mathrm{n}$ - jumlah variabel bebas $(\mathrm{dk}=63-1)$ dan $\alpha=0,05$ maka $t_{\text {tabel }}$ 1,99897 Berikut akan dijelaskan pengujian masing-masing variabel secara parsial:

Tabel 4

Hasil Uji T

Coefficients $^{a}$

\begin{tabular}{|c|c|c|c|c|c|c|}
\hline \multirow{2}{*}{\multicolumn{2}{|c|}{ Model }} & \multicolumn{2}{|c|}{$\begin{array}{l}\text { Unstandardized } \\
\text { Coefficients }\end{array}$} & \multirow{2}{*}{\begin{tabular}{|l} 
Standardized \\
Coefficients \\
Beta \\
\end{tabular}} & \multirow[b]{2}{*}{$\mathrm{t}$} & \multirow[b]{2}{*}{ Sig. } \\
\hline & & $B$ & Std. Error & & & \\
\hline \multirow[t]{2}{*}{1} & (Constant) & 18.244 & 4.324 & & 4.219 & .000 \\
\hline & Motivasi & .503 & .116 & .487 & 4.352 & .000 \\
\hline
\end{tabular}

a. Dependent Variable: Kinerja Pegawai

Sumber: Output SPSS 22, 2017

Berdasarkan tabel di atas, hasil uji $\mathrm{t}$ untuk variabel $X$ (Motivasi) diperoleh nilai thitung $=4,352$ dengan tingkat signifikansi 0,00. Dengan menggunakan batas 0,05 , didapat $t_{\text {tabel }}$ sebesar 1,99897. Ini berarti $t_{\text {hitung }}>t_{\text {tabel, }}$ yang berarti $\mathrm{Ho}$ ditolak dan $\mathrm{Ha}$ diterima. Dengan demikian berarti bahwa secara parsial Motivasi ada pengaruh yang signifikan terhadap kinerja karyawan. Dengan kata lain dapat disimpulkan bahwa motivasi yang diberikan baik, maka akan semakin baik kinerja karyawan.

\section{H. PEMBAHASAN}

Dalam penelitian terdapat dua variabel yaitu variabel Motivasi $(X)$ dan variabel Kinerja karyawan (Y). Motivasi merupakan daya penggerak yang menciptakan gairah kerja seseorang, agar mereka mau bekerja sama secara produktif untuk berhasil mencapai dan mewujudkan tujuan yang telah ditentukan (Hasibuan, 2010). Sedangkan Kinerja karyawan adalah hasil kerja yang dapat dicapai seseorang atau sekolompok orang dalam suatu organisasi dengan wewenang dan tanggung jawab masing-masing, dalam rangka upaya mencapai tujuan organisasi bersangkutan secara legal, tidak melanggar hukum dan sesuai dengan moral dan etika (Prawirosentono, 2015).

Berdasarkan hasil uji SPSS 22, Diperoleh persamaan $Y=18,244+$ $0,503 X$ artinya apabila nilai $(b=$ 0,503 ) menunjukkan bahwa setiap variabel motivasi ditingkatkan sebesar satu satuan, maka kinerja karyawan akan meningkat sebesar 0,503 satuan. Sebaliknya jika variabel motivasi 
diturunkan satu satuan maka kinerja karyawan akan menurun sebesar 0,503 satuan.

Dari hasil perhitungan koefisien korelasi $(\mathrm{R})$ diperoleh sebesar 0,687. Hal ini berarti variabel motivasi mempunyai hubungan yang cukup kuat terhadap kinerja karyawan PT. Hevea Bumi Sriwijaya dan hasil perhitungan koefisien determinasi ( $R$ Square) diperoleh sebesar 0,471. Hal ini berarti 47,1\% kinerja karyawan dapat dipengaruhi oleh variabel motivasi, sedangkan sisanya yaitu $52,9 \%$ kinerja karyawan dipengaruhi oleh variabel-variabel lainnya yang tidak diteliti dalam penelitian ini.

Berdasarkan hasil uji $t$ (uji hipotesis) untuk variabel Motivasi (X) terhadap variabel Kinerja karyawan $(Y)$ diperoleh nilai $t_{\text {hitung }}=4,352$ dengan tingkat signifikansi 0,00 . Dengan menggunakan batas 0,05 , didapat $t_{\text {tabel }}$ sebesar 1,99897. Ini berarti thitung $>t_{\text {tabel, }}$ yang berarti Ho ditolak dan Ha diterima. Dengan demikian berarti bahwa secara parsial Motivasi ada pengaruh yang signifikan terhadap kinerja karyawan pada PT. Hevea Bumi Sriwijaya. Dengan kata lain dapat disimpulkan bahwa jika karyawan bekerja dengan motivasi yang tinggi, maka kinerja yang dihasilkan seorang karyawan akan semakin baik.

\section{KESIMPULAN DAN SARAN \\ 1. Kesimpulan}

Berdasarkan hasil dan analisis data yang telah dilakukan sebelumnya, maka dapat disimpulkan sebagai berikut :

a) Motivasi memiliki pengaruh yang signifikan terhadap kinerja karyawan. Hal ini berarti apabila motivasi karyawan PT. Hevea Bumi Sriwijaya tinggi maka akan semakin baik kinerja yang dihasilkan oleh seorang karyawan di PT. Hevea Bumi Sriwijaya. b) Besarnya pengaruh variabel motivasi terhadap kinerja karyawan PT. Hevea Bumi Sriwijaya sebesar $47,1 \%$ sedangkan sisanya dipengaruhi faktor lain.

Nilai beta variabel motivasi sebesar $(b=0,503) \quad$ menunjukkan bahwa setiap variabel Motivasi ditingkatkan sebesar satu satuan, maka Kinerja karyawan akan meningkat sebesar 0,503 satuan. Sebaliknya jika variabel Motivasi diturunkan satu satuan maka kinerja karyawan akan menurun sebesar 0,503 satuan.

\section{Saran}

Penulis mencoba mengajukan beberapa saran yang diharapkan dapat menjadi masukan atau bahan pertimbangan mengenai pentingnya Motivasi dalam meningkatkan kinerja karyawan di PT. Hevea Bumi Sriwijaya, yaitu :

a) Diharapkan PT. Hevea Bumi Sriwijaya dapat meningkatkan dan menjaga motivasi yang dimiliki karyawannya dengan memperhatikan faktor-faktor yang dapat menumbuhkan motivasi seorang karyawan agar kinerja karyawan di PT. Hevea Bumi Sriwijaya selalu baik dan terus meningkat dari waktu ke waktu.

b) Hendaknya para pegawai di PT. Hevea Bumi Sriwijaya selalu berusaha untuk selalu menjaga dan meningkatkan motivasi yang ada dalam dirinya masing-masing demi tercapainya kinerja yang baik yang sangat berguna bagi kamajuan perusahaan mereka.

\section{DAFTAR PUSTAKA}

As'ad, Moh, 2011, Psikologi Industri, Yogyakarta: Liberty 
Brantas, 2010, Dasar-Dasar Manajemen, Bandung: AlfaBeta

Davis, Keith, 2012. Fundamental Organization Behavior, Diterjemahkan oleh Agus Dharma, Jakarta: Erlangga

Djamarah, Syaiful Bahri, 2011. Psikologi Belajar. Jakarta Rineka Cipta

Fahmi, Irham, 2015. Manajemen Kinerja, Teori dan Aplikasi. Bandung: Alfabeta

Hasibuan, Malayu S.P. 2010, Manajemen Sumber Daya Manusia, Jakarta: Bumi Aksara

Harsuku, R. 2011. Mendongkrak motivasi dan kinerja. Malang: Universitas Brawijaya Press.

Mahsun, Mohamad, 2010, Pengukuran Kinerja Sektor Publik, Yogyakarta: BPFE

Makmur, Syarif, 2011, Perberdayaan Sumber Daya Manusiadan Efektivitas Organisasi: Kajian Penyelenggaraan Pemerintah Desa,Jakarta: RajaGrafindo Persada

Mangkunegara, A., P, 2013. Manajemen Sumber Daya
Manusia Perusahaan, Bandung: Rosdakarya

Prawirasentono, Suyadi dan Dewi Primasari, 2015. Kinerja dan Motivasi Pegawai. Jogjakarta: BPFE Jogjakarta

Priyatno, Duwi 2016. Belajar Alat Analisis Data Dana Pengelolahannya Dengan SPSS. Yogyakarta : Penerbit Gava Media

Riduwan. 2012. Pengantar Statistik Pendidikan, Sosial, Ekonomi, Komunikasi dan Bisnis. (cet.3). Bandung, Indonesia: Alfabeta.

Riani, A., L. 2013. Manajemen Sumber Daya Manusia Masa Kini. Yogyakarta: Graha IImu.

Siregar, Syofian. 2013. Metode Penelitian Kuantitatif. Jakarta: PT Fajar Interpratama Mandiri.

Slamet, Syofian, 2017. Manajemen Sumber Daya Manusia. Semarang: Unnes Press

Sugiyono, 2017. Penelitian Kuantitatif dan Kualitatif dan $R \& D$. Bandung: Alfabeta

Wibowo, 2014. Manajemen Kinerja. Edisi keempat. Jakarta: PT Raja Grafindo Persada 